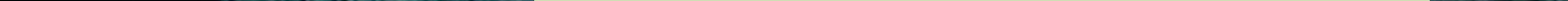


FOR OVER TWO DECADES, explorers of the deep ocean have been enthralled by volcanically driven black smoker hydrothermal systems hosting organisms that live under some of the most extreme conditions on Earth (e.g., Corliss et al., 1979; Jannasch and Mottle, 1985; Grassle, 1986; Delaney et al., 1992; Humphris et al., 1995; Humphris and Tive, 2000; Van Dover, 2000; German et al., 2004; Wilcock et al., 2004). These systems are found on some of the youngest, hottest rocks on our planet located along the global midocean ridge spreading network. Black smokers result from the seepage of seawater through cracks in the seafloor and its subsequent heating at depth by hot or molten basaltic rocks to temperatures $>400^{\circ} \mathrm{C}$ (e.g., Von Damm et al., 2003). The superheated fluid, which is rich in dissolved metals and gases from chemical exchange with the hot rock, buoyantly rises to the surface. Until a few years ago, the billowing jets of metal sulfide- and gas-laden fluids were believed to typify submarine hot spring systems. However, in 2000, a serendipitous discovery of an entirely new venting system was made that was as profound and surprising as that of the first black smokers (Kelley et al., 2001). This new venting system, called Lost City, is unlike any environment ever visited. Investigation of this site is changing our views not only about the conditions under which life can thrive on our planet but, perhaps, on others as well. 


\section{MOUNTAINS OF THE DEEP}

The Lost City Hydrothermal Field

(LCHF) is located $15 \mathrm{~km}$ west of the spreading axis of the Mid-Atlantic Ridge at $30^{\circ} \mathrm{N}$, near the summit of the Atlantis Massif (Blackman et al., 2002; Kelley et al., 2001, 2005). The relief of this mountain is similar to that of Mt. Rainier, rising nearly $4000 \mathrm{~m}$ above the seafloor over a horizontal distance of $\sim 20 \mathrm{~km}$

(Figure 1). Unlike Mt. Rainier, however, the Atlantis Massif is not formed by volcanic eruptions, but instead by extreme crustal extension and long-lived faulting and uplift. In concert, these processes have resulted in the stripping-off of shallow crustal volcanic material and exposure of magnesium-rich mantle rocks that were once deep beneath the Mid-Atlantic Ridge. The Atlantis Fracture Zone bounds the south face of the Atlantis Massif. Extensive faulting and mountain are about 1 to 2 million years in age (Blackman et al., 2002).

Because the mantle rocks that make up the Atlantis Massif were initially formed under high pressure and temperature, but are now exposed in a hydrous environment at or near the surface of the seafloor, they are out of equilibrium and react with seawater that migrates down into the mountain along fractures and smaller cracks. The reactions have resulted in extensive replacement of the mantle material by water-bearing minerals called serpentine. These hydrothermally altered rocks are called serpentinites. Long-lived faulting, extreme crustal extension, and exposure and alteration of shallow mantle material is characteristic of submarine mountains such as the Atlantis Massif, and the processes involved in their construction are probably critical to formation of Lost City-like systems.

This new venting system, called Lost City, is unlike any environment ever visited. Investigation of this site is changing our views not only about the conditions under which life can thrive on our planet but, perhaps, on others as well.

mass wasting along this face created a series of large embayments $(\sim 2 \mathrm{~km}$ across), separated by well-developed promontories. Lost City is located on one of these ridges at a water depth of $\sim 800 \mathrm{~m}$ (Figure 1). Based on magnetic surveys, the mantle and shallow crustal rocks that make up this portion of the

\section{DISCOVERY AND EXPLORATION OF LOST CITY}

The LCHF was discovered in December 2000 during a deep-sea camera survey designed to image the near vertical cliffs that are characteristic of much of the terrain near the summit of the massif (Kelley et al., 2001). Geologists Gretchen
Früh-Green (Eidgenössische Technische Hochschule, Zürich) and Barbara John (University of Wyoming) were leading the survey aboard the research vessel Atlantis, watching live video streamed to the ship over a fiber optic cable from a camera system 800 m below. During their watch, strange-looking snow-white deposits and pinnacles came in and out of view, marking the discovery of the field. A follow-on dive in the submersible Alvin by Deborah Kelley (the author, University of Washington), Jeffrey Karson (Duke University), and Patrick Hickey (Woods Hole Oceanographic Institution) showed that this site was like none previously seen, hosting actively venting carbonate chimneys that towered $60 \mathrm{~m}$ about the surrounding seafloor (http://earthguide.ucsd.edu/mar/dec12. html). The forest of stunning, tall white chimneys was reminiscent of Greek and Roman columns (Figure 2) (the tallest chimney is called Poseidon after the Greek god of the sea). The columnar nature of the pinnacles, combined with the field being located on the Atlantis Massif near the Atlantis Fracture Zone, and discovered by scientists on board the research vessel Atlantis, resulted in naming the field "Lost City."

In 2003, the field was intensely mapped, sampled, and explored for the first time during a 32-day expedition funded by the National Science Foundation (http://www.lostcity.washington. edu). Because the field had not been

Deborah S. Kelley (kelley@ocean.washington.edu) is Associate Professor, School of Oceanography, University of Washington, Seattle, WA, USA. 


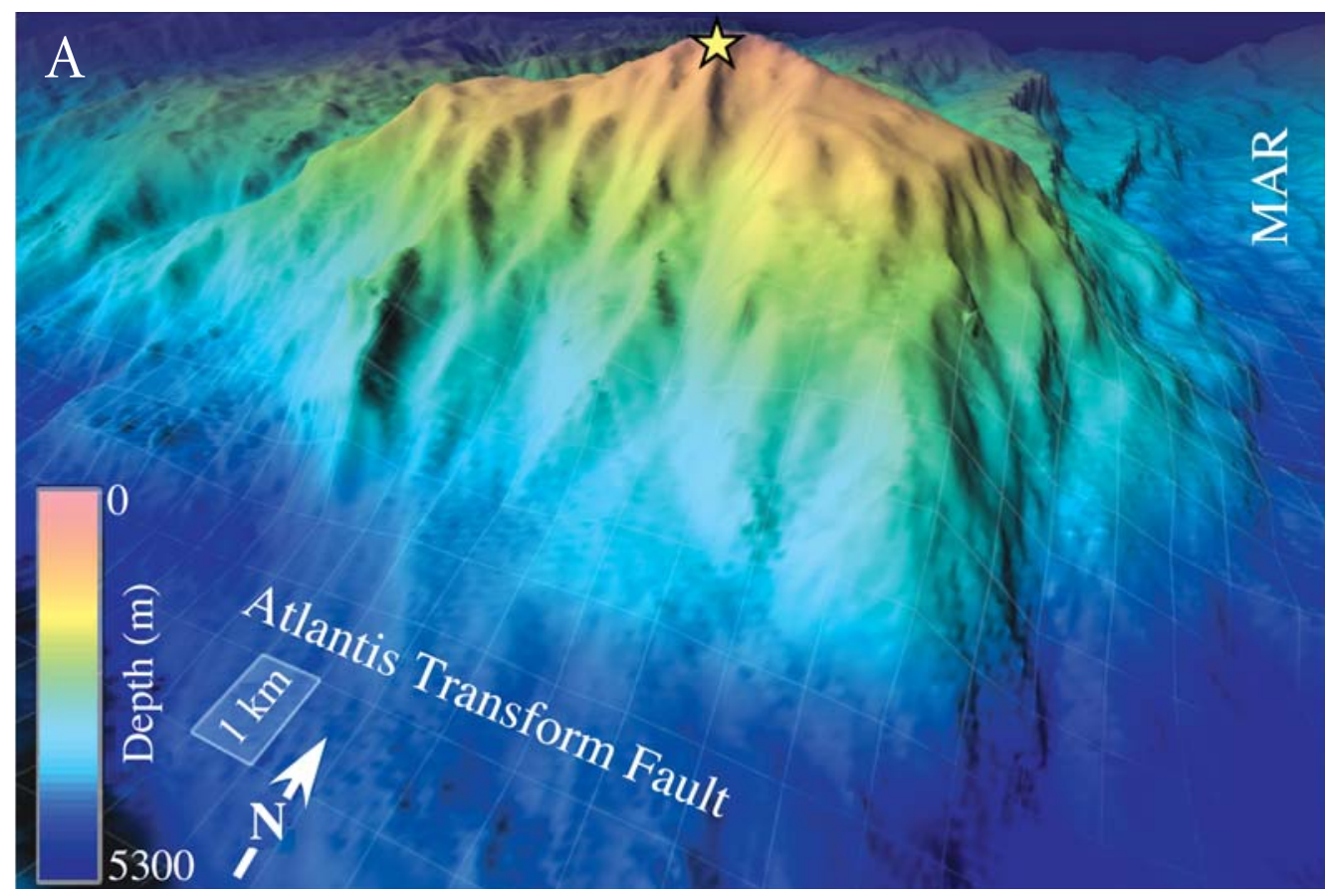

Figure 1. (A) The Atlantis Massif rises nearly $4000 \mathrm{~m}$ above the surrounding seafloor over a horizontal distance of $20 \mathrm{~km}$. Unroofing and uplift of the mountain have been achieved through long-lived faulting processes. The Atlantis Massif is underlain by variably serpentinized material, but seismic interpretations indicate that unaltered upper mantle is only < 300-500 m below the seafloor (Canales et al., 2004). Based on analyses of magnetic surveys, this mountain has experienced uplift rates $(1.5 \mathrm{~mm} / \mathrm{yr})$ as fast as those of the Himalayan mountains (Blackman et al., 2002). The Lost City Hydrothermal Field (LCHF) (yellow star) is located near the summit of the massif at a water depth of $\sim 800 \mathrm{~m}$. (B) Shaded bathymetric map based on SM2000 sonar data of the LCHF and adjacent terrane. These data were collected during surveys using the autonomous vehicle ABE. The LCHF field rests on a triangular-shaped, structural bench situated

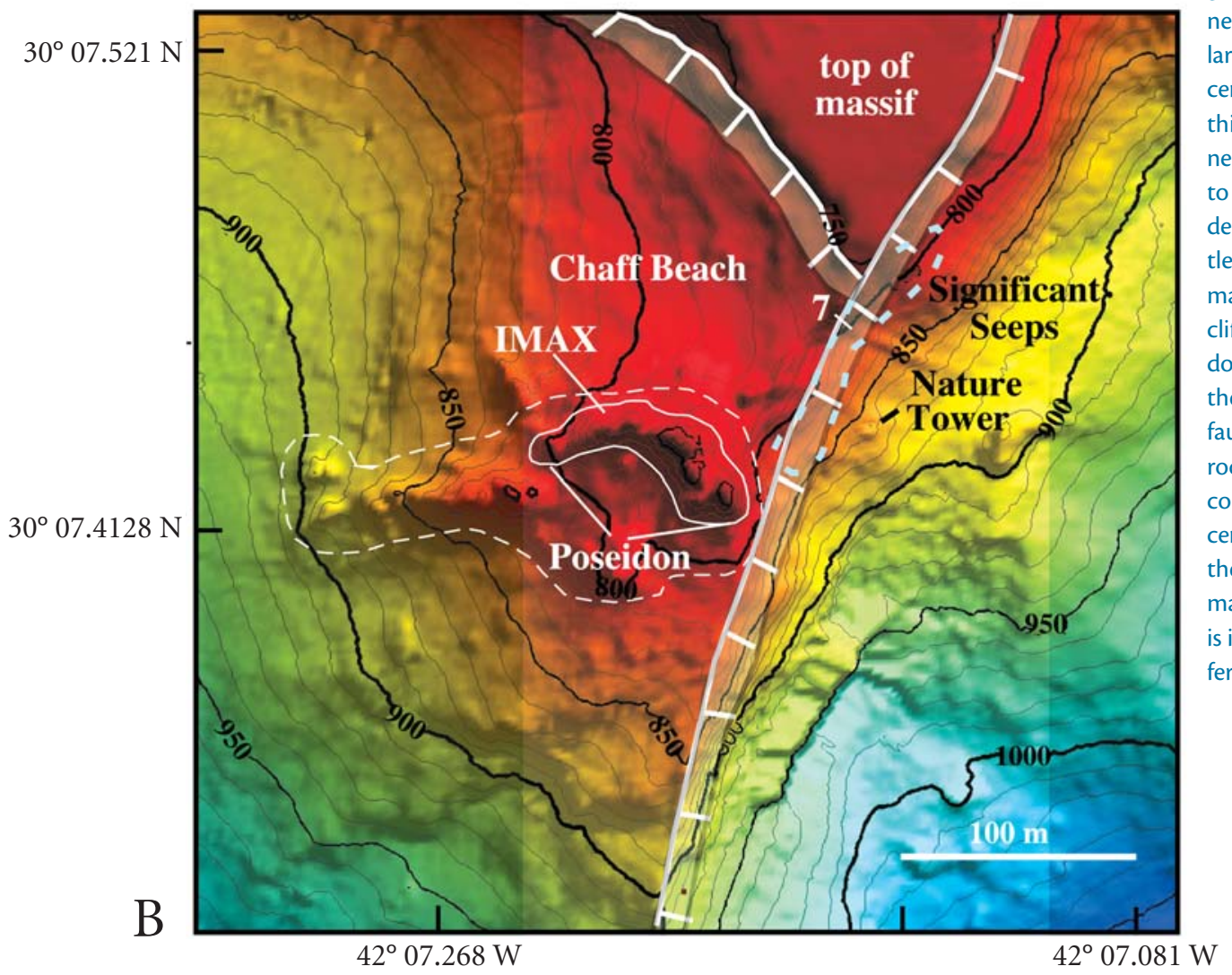
near the intersection of several, relatively large, steeply dipping zones near the central summit of the massif. An 50-mthick zone of intensely deformed rocks near the summit of the massif is believed to represent the surface of a long-lived detachment fault that exposed the mantle and lower crustal rock sequences that make up the massif. The $\sim 020$-trending cliffs to the east (hatched lines are on down-dropped sides of the faults) mark the surface location of a steep normal fault that cuts gabbroic and serpentinite rocks. The dashed white line marks the core of the field where there is 100 percent carbonate. On the eastern side of the field, fluids are weeping actively from many of the steep cliffs (main seep zone is indicated by blue dashed line). "7" refers to a pinnacle shown in Figure 3. 


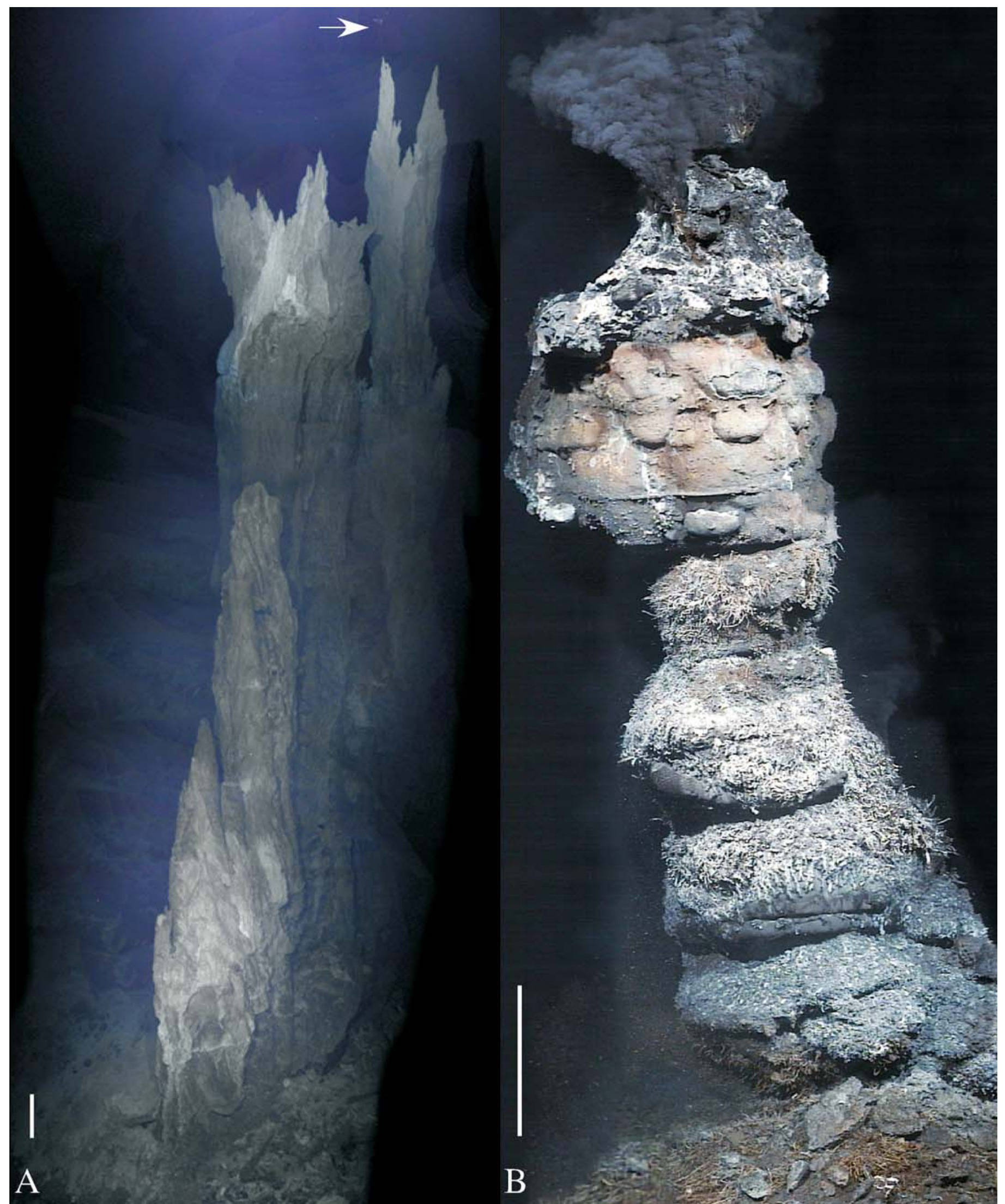

Figure 2. Contrasts between Lost City carbonate towers and black smoker chimneys. (A) Photomosaic of Nature Tower, a 30-m tall, actively venting carbonate chimney located on the east side of the field (see Figure 1) that rises out of the serpentinite bedrock. The most actively venting areas are bright white, while older areas are grey-brown in color. The small marker on the right pinnacle is $1 \mathrm{~m}$ tall (to right of arrow). (B) By contrast, this photomosaic of a $350^{\circ} \mathrm{C}$ black smoker edifice shows several features characteristic of structures within the volcanically driven hydrothermal system along the Endeavour Segment of the Juan de Fuca Ridge, Northeast Pacific Ocean. These $\mathrm{CO}_{2}$ - and $\mathrm{H}_{2} \mathrm{~S}$-rich systems support chemosynthetic microorganisms and dense and diverse macrofaunal communities (Kelley et al., 2002). This black smoker edifice is composed largely of metal sulfide and calcium-sulfate minerals with some amorphous silica, and sprouts small chimneys near its summit. Leaking of fluids through the porous chimney walls provides nutrients for tubeworm communities that thrive in the diffusely venting fluids. Phomosaics completed by Mitch Elend at the University of Washington using images taken with the submersible Alvin. Scale bar in each image is 1 meter. 
mapped previously in detail, an autonomous, small underwater vehicle called ABE (Autonomous Benthic Explorer) (Yoerger et al., 2000) was used to produce a very-high-resolution bathymetric map ( $<5 \mathrm{~m}$ resolution) of the entire field (Figure 1B). ABE was preprogrammed on board the ship, and when deployed it "dove" down to 50-100 m above the seafloor where it carried out survey operations using its SM2000 sonar system. Upon completion of the survey, $\mathrm{ABE}$ rose to the surface, was recovered on board the Atlantis, and bathymetric data were downloaded and processed. In addition, a variety of sensors on $\mathrm{ABE}$ were used to delineate the hydrothermal plume above the field (Jakuba et al., 2003).

This was the first time that $\mathrm{ABE}$ had "flown" in such steep terrain. However, during 17 night surveys the vehicle and its sonar system surveyed $200 \mathrm{~km}$ of seafloor, producing a remarkably detailed view of the field and adjacent terrain. Alvin dives during the day used nightly updates of $\mathrm{ABE}$ microbathymetric maps to plan follow-on dive programs. Because geological, chemical, and biological processes are so linked in this environment, wherever possible, co-registered rock, fluid, and biological samples where taken. Twenty-four scientists and students participated in this highly interdisciplinary program, with eight students diving to the seafloor for the first time. An active website during the cruise provided daily updates, and an avenue for the shipboard scientists and students to directly interact with $18 \mathrm{~K}-12$ classrooms across the country (http://www.lostcity.washington. edu/mission/classrooms.html).

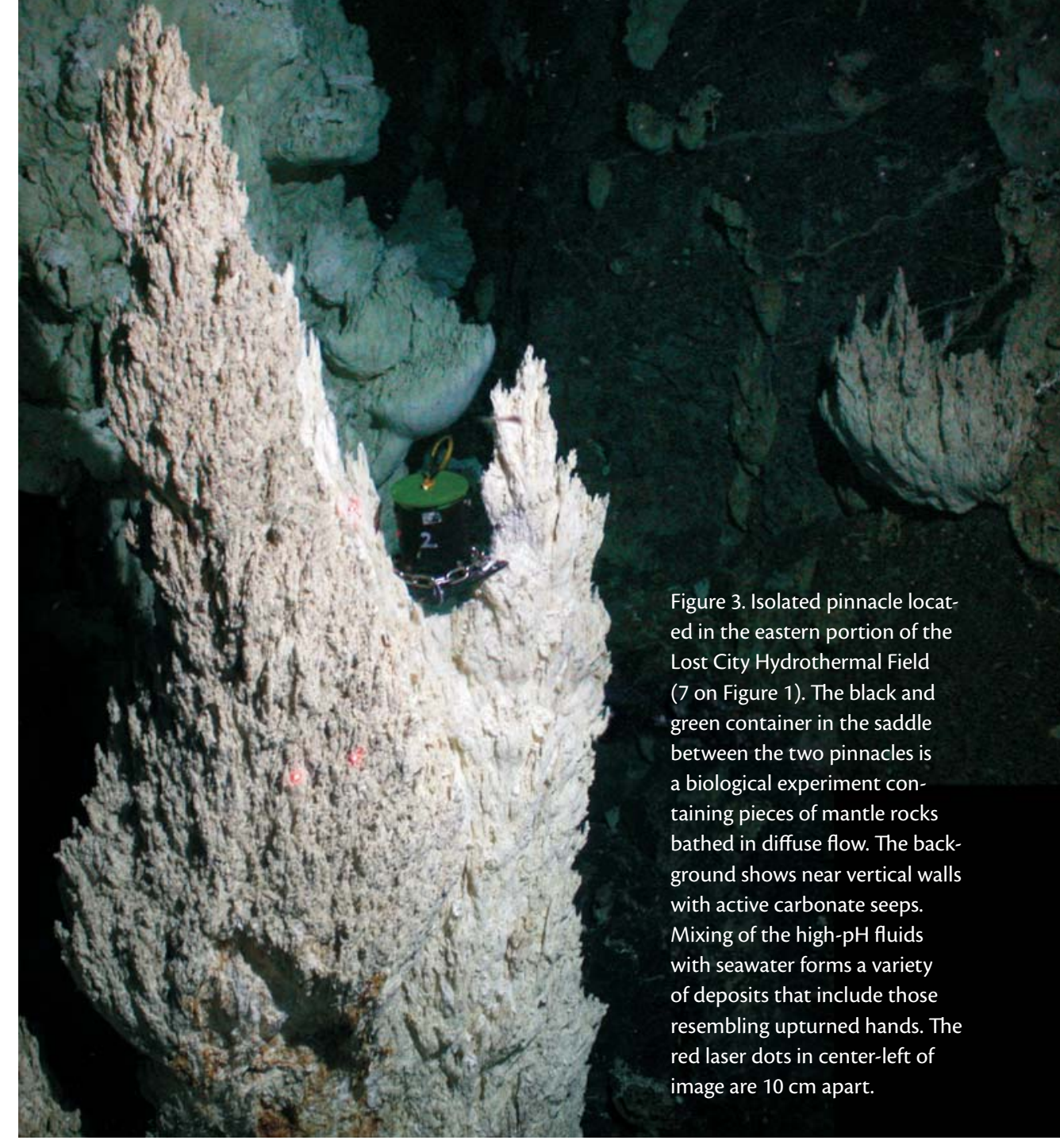

\section{A FIELD OF LIMESTONE TOWERS}

The LCHF rests on a triangular-shaped, structural bench situated at the intersection of several, relatively large, steeply dipping fault zones near the central summit of the massif (Figure 1B). The field extends for at least $400 \mathrm{~m}$ across the terrace, is bounded to the north by a small basin nicknamed Chaff Beach, and to the south by the Atlantis Transform Fault (Figure 1). An 50-m-thick zone of intensely deformed rocks near the summit of the massif is believed to represent the surface of a long-lived, low-angle fault that exposed the mantle and lower crustal rock sequences that make up the mas- sif. A set of $\sim 020$-trending cliffs to the east mark the surface of a steep normal fault that cuts the basement rocks. An array of gently westerly dipping fractures is concentrated within this zone, serving as conduits for flow. This is particularly evident in the eastern portion of the field where fluids are weeping actively from many of the steep cliffs (Figure 3). Upon mixing with seawater, the seep fluids precipitate carbonate that forms an array of spectacular deposits, which include: (1) up to $12 \mathrm{~m}$ tall, actively venting carbonate pinnacles that grow directly out of the vertical walls; (2) 1-m-across carbonate deposits that resemble upturned hands (Figure 3); (3) cascading, overlap- 
Figure 6. (A) Numerous chimney fragments are variably cemented with younger carbonate material. A large, dark block of serpentinite forms the base of a near vertical cliff. This image is taken with a downward-looking camera such that the pinnacle on the left side of the image is standing vertical. Some of the chimney fragments in this image are several meters in length. (B) Feathery, young carbonate deposits "sprouting" from older carbonate. The wreckfish in this image is $\sim 1 \mathrm{~m}$ in length. They are common within the field.

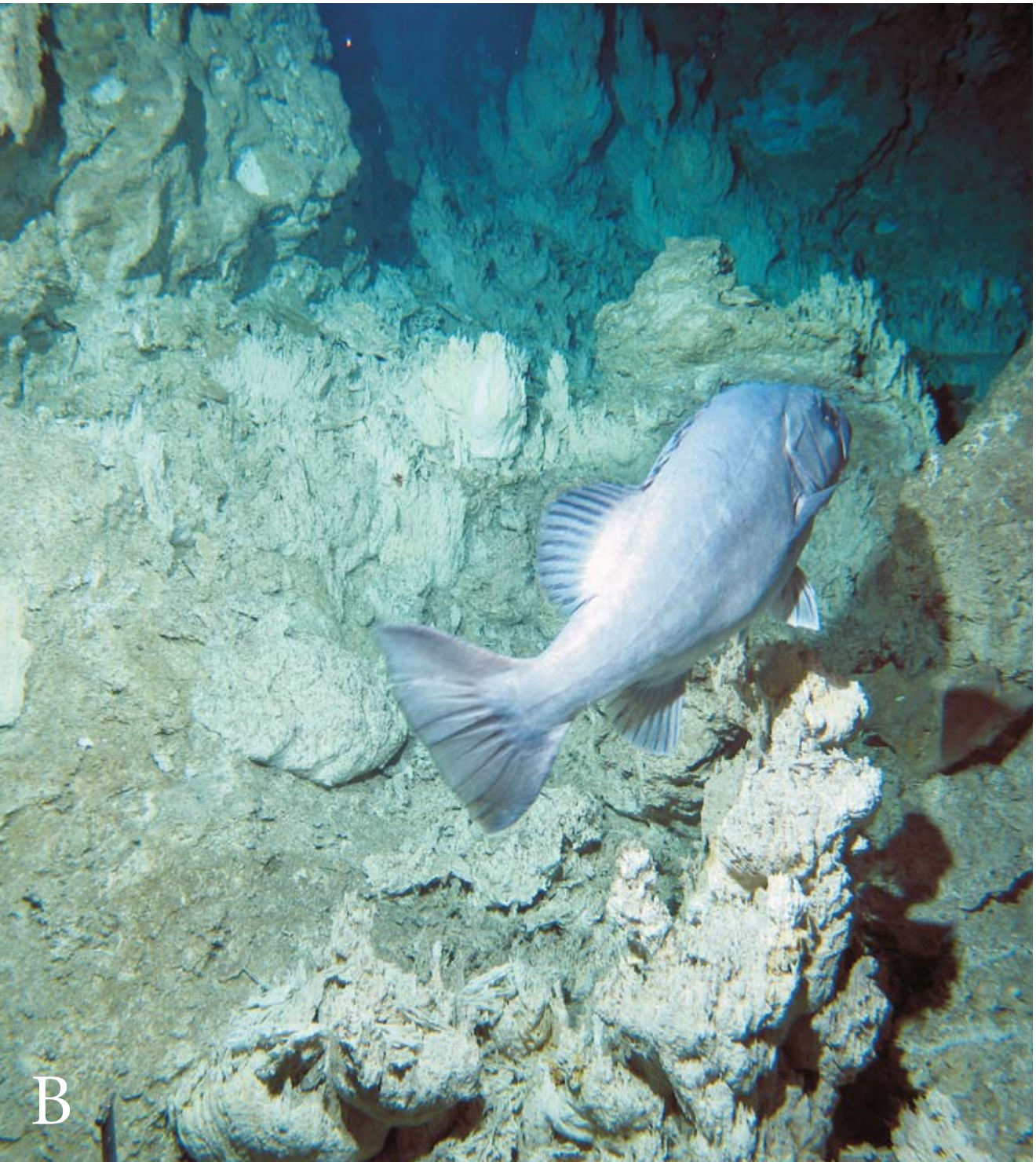

the carbonate minerals aragonite and calcite $(\mathrm{CaCO})$, with lesser amounts of brucite $\left[\mathrm{Mg}(\mathrm{OH})_{2}\right]$. The Lost City edifices do not contain any sulfide or sulfate minerals or amorphous silica, which are common constituents of high-temperature black smoker deposits (Table 1). During aging of the deposits, aragonite is progressively converted to calcite, and progressive seawater infiltration causes the brucite to dissolve. The end result is a deposit nearly solely composed of calcite. Older structures are brown in color, pitted, and knobby with the appearance of badly poured cement (Figure 7).

\section{CONNECTIONS BETWEEN THE}

\section{MANTLE AND LIFE}

The vent fluid chemistry and mineralogy and chemistry of the carbonate deposits at the LCHF are influenced by fluid-mineral reactions in the underlying mantle rocks (Kelley et al., 2001; Früh-Green et al., 2004; Kelley et al., 2005). These reactions are dominated by serpentinization reactions, which are driven by the instability of mantle-hosted olivine and 
Table 1. Generalized Characteristics of Black Smoker and “Lost City” Systems

\begin{tabular}{|c|c|c|}
\hline & Black Smoker Systems & Carbonate Systems \\
\hline Location & $\begin{array}{l}\text { Within axial valleys or along axial crests of spread- } \\
\text { ing centers, predominantly on young, hot, basaltic } \\
\text { crust }^{1-5}\end{array}$ & $\begin{array}{l}15 \mathrm{~km} \text { away from the spreading center on 1.5-2 my } \\
\text { old crust }^{6}\end{array}$ \\
\hline Abundance & $\begin{array}{l}\text { Found virtually on all mid-ocean ridges studied in } \\
\text { any detail }\end{array}$ & $\begin{array}{l}\text { Lost City is only known field (unlikely that is } \\
\text { unique, however) }\end{array}$ \\
\hline Heat Source & Fueled by cooling of submarine volcanoes & $\begin{array}{l}\text { Fueled by exothermic fluid-mineral reactions } \\
\text { (serpentinization) and lithospheric cooling }{ }^{6-8}\end{array}$ \\
\hline Host Rocks & $\begin{array}{l}\text { Typically hosted on volcanic rocks, though some } \\
\text { fields, such as Logatchev and Rainbow, are on inter- } \\
\text { mixed gabbro and mantle rocks }{ }^{4-5,9}\end{array}$ & $\begin{array}{l}\text { On altered mantle rocks (serpentinites), with lesser } \\
\text { gabbro (slowly cooled magma) }\end{array}$ \\
\hline $\begin{array}{l}\text { Venting } \\
\text { Temperatures }\end{array}$ & $\begin{array}{l}\text { Temperatures typically }>300^{\circ} \mathrm{C} \text {, some as hot as } \\
407^{\circ} \mathrm{C} \text {, also host low-temperature diffuse systems } \\
\left(<100^{\circ} \mathrm{C}\right)^{1-5}\end{array}$ & $\begin{array}{l}\text { 40-90 }{ }^{\circ} \mathrm{C} \text {, very rare, distinct, annular orifices, } \\
\text { dominantly diffusely venting structures }\end{array}$ \\
\hline $\begin{array}{l}\text { Fluid } \\
\text { Compositions }\end{array}$ & $\begin{array}{l}\text { Acidic ( } \mathrm{pH} 2-5 \text { ), metal- and sulfide-rich, variable } \\
\text { amounts of silica, no } \mathrm{Mg} \text {, no } \mathrm{SO}_{4}^{1-5}\end{array}$ & $\begin{array}{l}\text { Basic ( } \mathrm{pH} \text { 9-11), extremely poor in metals and silica, } \\
\text { enriched in } \mathrm{Ca} \text {, some } \mathrm{SO}_{4} \text {, very low to no } \mathrm{Mg}^{6}\end{array}$ \\
\hline $\begin{array}{l}\text { Volatile } \\
\text { Compositions }\end{array}$ & $\begin{array}{l}\text { Dissolved volatiles are dominated by volcanically- } \\
\text { derived } \mathrm{CO}_{2}, \mathrm{He}, \mathrm{H}_{2} \mathrm{~S} \text {, but also contain } \mathrm{H}_{2} \text { and } \mathrm{CH}_{4}^{3-5,9}\end{array}$ & $\begin{array}{l}\text { Significantly enriched in } \mathrm{H}_{2} \text { and } \mathrm{CH}_{4} \text { derived from } \\
\text { fluid-rock reactions, enriched in hydrocarbons }{ }^{4,6-10}\end{array}$ \\
\hline Plumes & $\begin{array}{l}\text { Extensive, particle-laden plumes rising } 200 \mathrm{~m} \text { in wa- } \\
\text { ter column }{ }^{3-5}\end{array}$ & $\begin{array}{l}\text { Minor plumes, }<50 \mathrm{~m} \text { rise height, virtually particle } \\
\text { free }\end{array}$ \\
\hline $\begin{array}{l}\text { Chimney } \\
\text { Mineralogy }\end{array}$ & $\begin{array}{l}\text { Typically metal-rich structures commonly include: } \\
\text { chalcopyrite, pyrite, sphalerite, amorphous silica, } \pm \\
\text { barite, } \pm \text { anhydrite }{ }^{1-5,9}\end{array}$ & $\begin{array}{l}\text { Carbonate-dominated: aragonite, calcite, lesser } \\
\text { brucite. In areas actively venting, carbonate likely } \\
\text { nucleates on filamentous bacterial strands }{ }^{6,10}\end{array}$ \\
\hline Microorganisms & $\begin{array}{l}\text { Very dense and diverse colonies of Eubacteria and } \\
\text { Archaea. Significant colonies of chemosynthetic } \\
\text { organisms that utilize } \mathrm{H}_{2} \mathrm{~S}, \mathrm{H}_{2} \text {, and } \mathrm{CO}_{2}^{3-5,9}\end{array}$ & $\begin{array}{l}\text { Dense colonies of Eubacteria with high diversity, Ar- } \\
\text { chaea dominated by single group of organisms that } \\
\text { produce and/or oxidize } \mathrm{CH}_{4}, \mathrm{H}_{2} \text { and } \mathrm{SO}_{4} \text { utilization } \\
\text { important in cooler areas with higher diversity } y^{4,6,9,10}\end{array}$ \\
\hline Macrofauna & $\begin{array}{l}\text { Dense and diverse with colonies of large animals that } \\
\text { include tubeworms, clams, shrimp, mussels, crabs, } \\
\text { limpets }^{11}\end{array}$ & $\begin{array}{l}\text { Low biomass with organisms commonly }<1 \mathrm{~cm} \text { in } \\
\text { size, dominated by gastropods. Very rare crabs and } \\
\text { shrimp, surprisingly high diversity of mega/macro- } \\
\text { fauna, some related to MOR black smoker fauna }{ }^{6}\end{array}$ \\
\hline
\end{tabular}

'Corliss et al., 1979; ${ }^{2}$ Delaney et al., 1992; ${ }^{3}$ Humphris et al., 1995; ${ }^{4}$ Kelley et al., 2000; ${ }^{5}$ German et al., 2004; ${ }^{6}$ Kelley et al., 2001, 2005; ${ }^{7}$ Früh-Green et al., 2003 ;

${ }^{8}$ Früh-Green et al., 2004; ${ }^{2}$ Wilcock et al., 2004; ${ }^{10}$ Schrenk et al., 2004; ${ }^{11}$ Van Dover, 2000.

pyroxene mineral phases in the presence of heated seawater. Serpentinization is of fundamental importance, not only to the fluid and rock chemistry within the Lost City system, but it is also critical in formation of volatile phases, heat pro- duction, and evolution of the plumbing system (Früh-Green et al., 2004). During serpentinization, the mineral olivine $\left[(\mathrm{Mg}, \mathrm{Fe})_{2} \mathrm{SiO}_{4}\right]$ is progressively hydrated to form a variety of serpentine minerals (e.g., antigorite $\left[(\mathrm{Mg}, \mathrm{Fe})_{3} \mathrm{Si}_{2} \mathrm{O}_{5}(\mathrm{OH})_{4}\right]$ ) and $\mathrm{Fe}^{2+}$ in olivine and other minerals is converted to $\mathrm{Fe}^{3+}$ to form the iron oxide mineral magnetite $\left(\mathrm{Fe}_{3} \mathrm{O}_{4}\right)$. During this reaction, significant hydrogen $\left(\mathrm{H}_{2}\right)$ is produced by reduction of water during iron oxidation and the resultant reduc- 


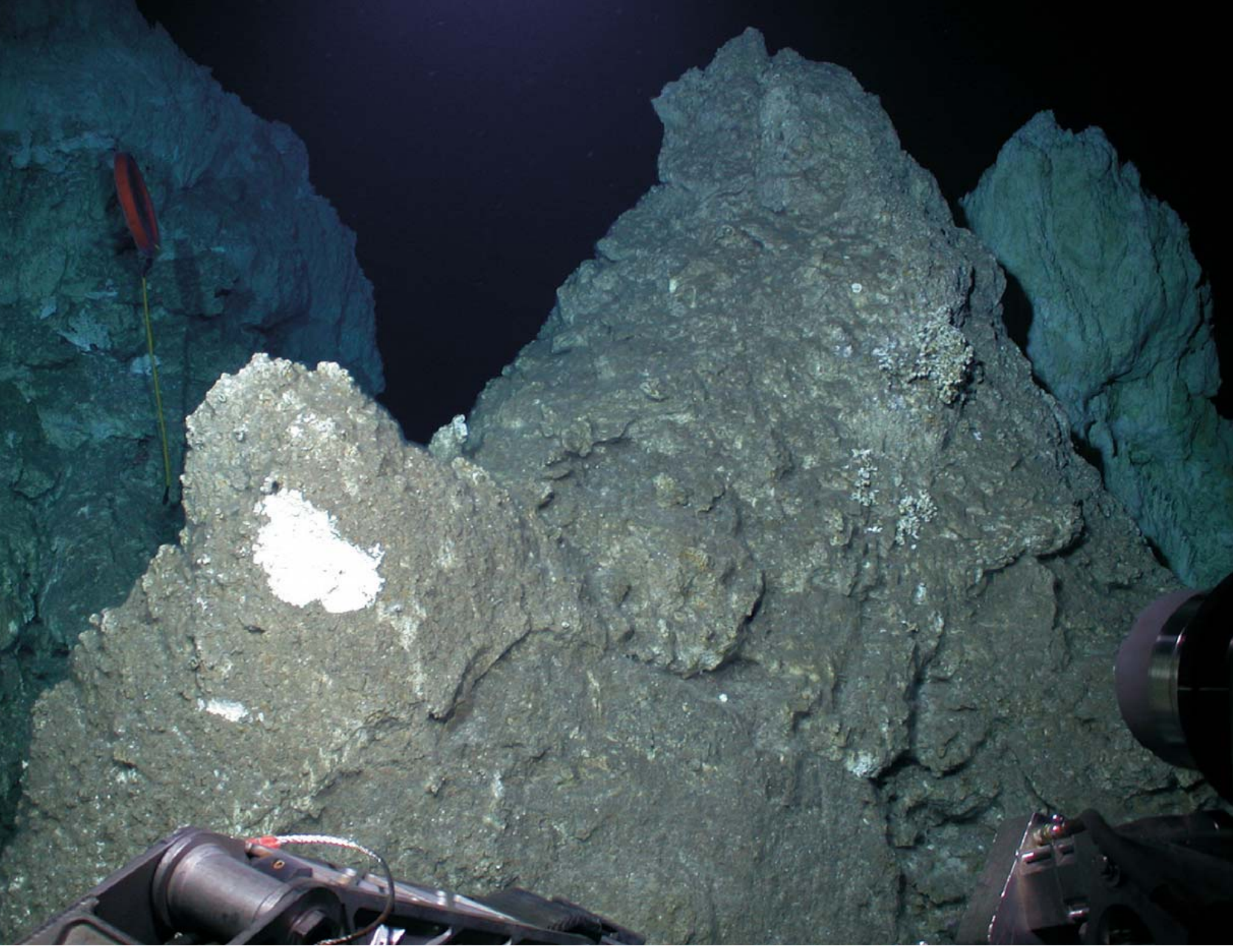

Figure 7. The brown-grey chimney in the foreground is an old, extinct deposit located at the summit of Poseidon. The knobby, rounded appearance is typical of older deposits. A variety of corals commonly grow on areas that are not actively venting. The yellow marker line is $1 \mathrm{~m}$ in length. Dating of carbonate material within the field shows that it has been active for at least 30,000 years.

ing conditions, coupled with reactions that involve iron-nickel alloys (which act as catalysts), promote the conversion of carbon in the system to methane $\left(\mathrm{CH}_{4}\right)$ and other hydrocarbons (Foustoukos and Seyfried, 2004). The resultant fluids are also enriched in $\mathrm{Ca}$, are alkaline, and have high pH (Palandri and Reed, 2004). The physical properties of the rocks also undergo dramatic changes whereby rock volumes may increase by as much as
20-50\%. This expansion has a profound influence on rock permeability distribution (O’Hanley, 1996; Früh-Green et al., 2004). Perhaps one of the most striking results of serpentinization, however, is that it is an exothermic reaction whereby heat is released. Modeling indicates that these reactions may produce enough heat to drive hydrothermal flow at temperatures $<200^{\circ} \mathrm{C}$ for thousands of years (Lowell and Rona, 2002; Früh-
Green et al., 2003).

Beneath the Lost City system, serpentinization reactions in the subsurface produce Ca-enriched (up to $30 \mathrm{mmol} / \mathrm{kg}$ vs $10.4 \mathrm{mmol} / \mathrm{kg}$ seawater), high $\mathrm{pH}$ fluids ( $\mathrm{pH}=9-11$ versus $\sim 8$ for seawater) that have temperatures between $40^{\circ} \mathrm{C}$ to $91^{\circ} \mathrm{C}$ (Kelley et al., 2005) (Table 1). Upon mixing with seawater, calcite precipitation is driven by the reaction $\mathrm{Ca}^{2+} \mathrm{HCO}_{3}^{-}+\mathrm{OH}^{-} \rightarrow \mathrm{CaCO}_{3}$ (solid) $+\mathrm{H}_{2} \mathrm{O}$ 
In this reaction, the $\mathrm{OH}^{-}$and some of the $\mathrm{Ca}^{2+}$ are from the hot venting fluid, while much of the $\mathrm{HCO}_{3}^{-}$and some of the $\mathrm{Ca}^{2+}$ are from the cold seawater that mixes with the venting fluid. The purest vent fluids contain little if any magnesium, therefore, brucite precipitation results from the mixing of concentrated hydrox-

\section{NEW BIOTOPES IN THE DEEP OCEAN}

Active structures within the LCHF are typically awash in buoyantly rising mixtures of warm, nutrient-rich vent fluid and cooler seawater. The diverse environmental conditions result in a variety of biotopes within the carbonate and ser-

The recent recognition of a potentially vast, as yet unexplored hot microbial biosphere associated with both active volcanism and serpentinization along the global mid-ocean ridge spreading network is fundamentally shifting concepts of how planets and life may co-evolve.

ide $\left(\mathrm{OH}^{-}\right)$in the vent fluids with seawater-derived magnesium. The concentrations of metals and silica in the vent fluids are very low, but they are enriched in $\mathrm{CH}_{4}$ (1-2 mmol/kg) and $\mathrm{H}_{2}$ (up to 15 $\mathrm{mmol} / \mathrm{kg}$ ) and have elevated concentrations of hydrocarbons relative to seawater (Proskurowski et al., 2004). Both $\mathrm{CH}_{4}$ and $\mathrm{H}_{2}$ are formed abiotically during serpentinization processes (Kelley et al., 2005). However, unlike in black smoker systems, the purest vent fluids contain very little if any carbon dioxide $\left(\mathrm{CO}_{2}\right)$ (a volatile derived from magma degassing and/or leaching of the magmatic gas from minerals during hydrothermal alteration). This difference has a profound affect on the microbiological communities at Lost City because the organisms have had to develop metabolisms that do not necessarily involve chemosynthetic processes based on $\mathrm{CO}_{2}$. pentinite rocks. These biotopes harbor concentrations of microbes similar to those in black smoker environments $\left(10^{7}\right.$ to $10^{8}$ cells per gram of wet weight; each cell is typically $\sim 1$ micron in size) (Kelley et al., 2005). However, the Lost City system differs dramatically from chemosynthetically-based communities in black smoker environments in that there is a strikingly low diversity of microorgan- isms within the warm interior walls of the carbonate towers whose metabolisms do not appear to require $\mathrm{CO}_{2}$.

In the highest-temperature, oxygenabsent zones within the interiors of the chimneys $\left(>90^{\circ} \mathrm{C}\right)$, biofilms of singlecelled organisms called Archaea form that may be capable of both methane production and methane oxidation. These Archaea show a surprisingly low diversity based on their genetic makeup. They are dominated by a single group of organisms related to Methanosarcinales (Schrenk et al., 2004; Kelley et al., 2005), which are common in methane seep environments along continental margins (Orphan et al., 2001). Other methane-consuming organisms, including an organism related to an anaerobic methane-oxidizing phylotytpe (ANME1) are present in moderate-temperature environments such as the flanges $\left(40^{\circ} \mathrm{C}\right.$ to $70^{\circ} \mathrm{C}$ ), where there is sustained mixing of pure vent fluids and seawater. They are also present in cool carbonate vein environments $\left(<40^{\circ} \mathrm{C}\right)$ that cut the serpentinite bedrock.

Bacterial colonies grow on the outside of diffusely venting chimneys where they form white to light grey filamentous strands several centimeters in length that
Perhaps the most far-reaching impact of the discovery of both black smoker and Lost City-

type systems is the realization that life itself may have originated within these dynamic environments in which geological, chemical, and biological processes are intimately linked. 
contain millions of microorganisms.

These venting areas are high-energy en-

vironments because of the mixing of oxygen- and sulfate-rich cool seawater, and high-temperature hydrothermal flu-
2005). Perhaps one of the most surprising finds is that the diversity of animals at Lost City is as high or higher than that of black smoker systems along the MidAtlantic Ridge (Kelley et al., 2005).

\section{The discovery of seafloor hydrothermal}

$$
\text { ecosystems that do not require magmatic }
$$

heat may have important implications in

$$
\text { our search for life on other planets. }
$$

ids enriched in methane and hydrogen. Based on 16S rDNA clone libraries, there is a relatively high diversity of organisms in these zones that include Eubacteria as well as Archaea (Schrenk et al., 2004).

In contrast to the dense macrofaunal assemblages that typify most known high-temperature vent environments (e.g., Van Dover, 2000), the biomass at Lost City is much smaller. The animals that live within the pores and small cavities on the outsides of the chimneys are typically $<1 \mathrm{~cm}$ in size, with transparent to translucent shells that make them very difficult to see in the field. These animals include a variety of gastropods, polychaetes, and amphipods. Rare, larger animals include crabs, shrimp, sea urchins, eels, and a diverse array of corals. The corals are particularly abundant at the top of the massif where strong currents are frequent. Wreckfish, up to $\sim 1.5$ $\mathrm{m}$ in length, are common (Figure $6 \mathrm{~B}$ ). Current assessment at Lost City shows that 58 percent of the fauna are endemic to this vent environment (Kelley et al.,

\section{IS LOST CITY UNIQUE?}

The recent recognition of a potentially vast, as yet unexplored hot microbial biosphere associated with both active volcanism and serpentinization along the global mid-ocean ridge spreading network is fundamentally shifting concepts of how planets and life may co-evolve. Perhaps the most far-reaching impact of the discovery of both black smoker and Lost City-type systems is the realization that life itself may have originated within these dynamic environments in which geological, chemical, and biological pro- cesses are intimately linked. Such is the view of Russell and Martin (2004), who suggests that the combination of a high $\mathrm{pH}$, reducing system such as Lost City, with a $\mathrm{CO}$-enriched Hadean ocean (4.6 to 3.8 billion years ago) was an optimal environment to get early biochemistry started. The discovery of seafloor hydrothermal ecosystems that do not require magmatic heat may have important implications in our search for life on other planets. The certainty that water exists, and has existed on Mars where there is good evidence for rocks rich in olivine, and the presence of a liquid ocean on Europa raises the question of whether systems similar to LCHF may be present (or have once been present) elsewhere in the solar system.

\section{ACKNOWLEDGMENTS}

Thanks much to Daniel J. Fornari, Michael Perfit, and Margaret Tivey for their thoughtful reviews and helpful editing of this manuscript. I am also deeply appreciative of the crew of the Atlantis, and of the Alvin and Argo teams for their continued friendship, hard work, and continued support. Special thanks to Daniel J. Fornari for the loan of his deep-sea digital cameras during the 2003
The certainty that water exists, and has existed on Mars where there is good evidence for rocks rich in olivine, and the presence of a liquid ocean on Europa raises the question of whether systems similar to LCHF may be present (or have once been present) elsewhere in the solar system. 
expedition. This work summarizes results from the 2003 Lost City research team (http://www.lostcity.washington. edu/mission/sciencecrew.html), which I have had the privilege to work with. This work was supported by a grant from the National Science Foundation. Additional information on Lost City can be found at http://www.oceanexplorer.noaa. gov/explorations/05lostcity/welcome. html. This site provides highlights of a 10-day expedition at Lost City in 2005, sponsored by the National Oceanic and Atmospheric Administration, the University of Washington, Institute for Exploration, Immersion Presents, and the Jason Foundation. 四

\section{REFERENCES}

Blackman, D.K., J.A. Karson, D.S. Kelley, J.R. Cann, G.L. Früh-Green, J.S. Gee, S.D. Hurst, B.E. John, J. Morgan, S.L. Nooner, D.K. Ross, T.J. Schroeder, and E.A. Williams. 2002. Geology of the Atlantis Massif (Mid-Atlantic Ridge, $30^{\circ} \mathrm{N}$ ): Implications for the evolution of an ultramafic oceanic core complex. Marine Geophysical Research 23:443-469.

Canales, J.P., R.E. Tucholke, J.A. Collins. 2004. Seismic reflection imaging of an oceanic detachment fault: Atlantis megamullion (Mid-Atlantic Ridge, $30^{\circ} \mathrm{N}$ ). Earth Planetary Science Letters 222:543-560.

Corliss, J.B., J. Dymond, L.I. Gordon, J.M. Edmond, R.P. von Herzen, R.D. Ballard, K. Green, D. Williams, A. Bainbridge, K. Crane, and T.H. van Andel. 1979. Submarine thermal springs on the Galapagos Rift. Science 203:1,073-1,083.

Delaney, J.R., V. Robigou, R.E. McDuff, and M.K. Tivey. 1992. Geology of a vigorous hydrothermal system on the Endeavour Segment, Juan de Fuca Ridge. Journal of Geophysical Research 97:19,66319,682 .

Foustoukos, D.I. and W.E. Seyfried Jr. III. 2004. Hydrocarbons in vent fluids: The role of chrome-bearing catalysts. Science 304:1,002-1,005.

Früh-Green, G.L., D.S. Kelley, S.M. Bernasconi, J.A. Karson, K.A. Ludwig, D.A. Butterfield, C. Boschi, and G. Proskurowski. 2003. 30,000 years of hydrothermal activity at the Lost City vent field. Science 301:495-498.

Früh-Green, G.L., J.A.D. Connolly, A. Plas, D.S. Kelley, and B. Grobety. 2004. Serpentinization of oceanic peridotites: Implications for geochemical cycles and biological activity. Pp.119-136 in The Subseafloor Biosphere at Mid-Ocean Ridges, S.D.
Wilcock, E.F. Delong, D.S. Kelley, J.A. Baross, and S.C Cary. Geophysical Monograph 144. American Geophysical Union, Washington DC.

German, C.R., J. Lin, L. Parsons. 2004. Mid-Ocean Ridges Hydrothermal Interactions Between the Lithosphere and Oceans. Geophysical Monograph 148. American Geophysical Union, Washington DC, 318 pp.

Grassle, J.F. 1986. The ecology of deep-sea hydrothermal vent communities. Advances in Marine Biology 23:301-362.

Humphris, S.E., R.A. Zierenberg, L.S. Mullineau and R.E. Thomson. 1995. Seafloor Hydrothermal Systems Physical, Chemical, Biological, and Geological Interactions. Geophysical Monograph 91. American Geophysical Union, Washington D.C., 466 pp.

Humphris, S.E., and M.K. Tivey. 2000. A synthesis of geological and geochemical investigations of the TAG hydrothermal field: Insights into fluid-flow and mixing processes in a hydrothermal system. Geological Society of America Special Paper 349:213235.

Jakuba, M.V., D.R. Yoerger, A.M. Bradley, D.S. Kelley, J.A. Karson. 2003. High resolution multibeam sonar mapping of the Lost City hydrothermal site with the Autonomous Benthic Explorer. Eos Trans. AGU 84(46, Fall Meet. Suppl.):B12A-0772.

Jannasch, H.W., and M.J. Mottl. 1985. Geomicrobiology of deep-sea hydrothermal vents. Science 229:717-725.

Kelley, D.S., J.A. Karson, D.K. Blackman, Gretchen Früh-Green, Jeff Gee, D.A. Butterfield, M.D. Lilley, E. J. Olson, M.O. Schrenk, K.R. Roe, and Shipboard Scientific Party. 2001. An off-axis hydrothermal vent field near the Mid-Atlantic Ridge at $30^{\circ} \mathrm{N}$. Nature 412:145-149.

Kelley, D.S., J.A. Baross, and J.R. Delaney. 2002. Volcanoes, Fluids, and Life in Submarine Environments. Annual Review Earth and Planetary Science 30:385-491.

Kelley, D.S., J.A. Karson, G.L. Früh-Green, D. Yoerger, T.M. Shank, D.A. Butterfield, J.M. Hayes, M.O. Schrenk, E. Olson, G. Proskurowski, M. Jakuba, A. Bradley, B. Larson, K.A. Ludwig, D. Glickson, K. Buckman, A.S. Bradley, W.J. Brazelton, K. Roe, M. Elend, A.G. Delacour, S.M. Bernasconi, M.D. Lilley, J.A. Baross, R.E. Summons, and S.P. Sylva. 2005. A serpentinite-hosted ecosystem: The Lost City Hydrothermal Field. Science 307:1,428-1,434.

Koski, R.A., I.R. Jonasson, D.C. Kadko, V.K. Smith, and F.L. Wong. 1994. Composition, growth mechanisms, and temporal relations by hydrothermal sulfide-sulfate-silica chimneys at the northern Cleft Segment, Juan de Fuca Ridge. Journal Geophysical Research 99:4,813-4,832.

Langmuir, C., S. Humphris, D. Fornari, C. Van Dover, K. Von Damm, M.K. Tivey, D. Colodner, J.-L Charlou, D. Desonie, C. Wilson, Y. Fouquet, G. Klinkhammer, and H. Bougault. 1997. Hydrothermal vents near a mantle hot spot: the Lucky Strike vent field at $37^{\circ} \mathrm{N}$ on the Mid-Atlantic Ridge. Earth and
Planetary Science Letters 148:69-91.

Lowell, R.P., and P.A. Rona. 2002. Seafloor hydrothermal systems driven by the serpentinization of peridotite. Geophysical Research Letters 29:10.1029/ $2001 G L 014411$.

Palandri, J.L. and M.H. Reed. 2004. Geochemical models of metasomatism in ultramafic systems: Serpentinization, rodingitization, and seafloor carbonate chimney precipitation. Geochemica Cosmochimica Acta 68:1,115-1,133.

Proskurowski, G., M.D. Lilley, G.L. Früh-Green, E.J. Olson, and D.S. Kelley. 2004. The use of stable hydrogen isotopes as a geothermometer in hydrothermal systems. Eos Trans. AGU 85(47, Fall Meet. Suppl.):B13A-0200.

O’Hanley, D.S. 1996. Serpentinites Records of Tectonic and Petrological History. Oxford Monographs on Geology and Geophysics 34. New York Oxford University Press, 277 pp.

Orphan, V.J., K.-U Hinrichs, W. Ussler III, C.K. Paull, L.T. Taylor, S.P. Sylva, J.M. Hayes, and E.F. Delong. 2001. Comparative analysis of methane-oxidizing archaea and sulfate-reducing bacteria in anoxic sediments. Applied and Environmental Microbiology 67(4):1,922-1,934.

Robigou, V., J.R. Delaney, and D.S. Stakes. 1993. Large massive sulfide deposits in a newly discovered active hydrothermal system, the High-Rise, Endeavour Segment, Juan de Fuca Ridge. Geophysical Research Letters 20:1,887-1,890.

Russell, M.J., and W. Martin. 2004. The rocky roots of the acetyl-CoA pathway. TRENDS in Biochemical Sciences 29:358-363.

Schrenk, M.O., D.S. Kelley, S. Bolton, J.D. Baross. 2004. Low archaeal diversity linked to sub-seafloor geochemical processes at the Lost City Hydrothermal Field, Mid-Atlantic Ridge. Environmental Microbiology 6(10):1,086-1,095.

Van Dover, C.L. 2000. The Ecology of Deep-Sea Hydrothermal Vents. Princeton University Press, Princeton, New Jersey, 424 pp.

Von Damm, K.K., M.D. Lilley, W.C. Shanks III, M. Brockington, A.M. Bray, K.M. O-Grady, E. Olson, A. Graham, G. Proskurowski, R. Collier, J. Cowen, R. Haymon, M.K. Tivey, D. Fornari, K. Nakamura, E. McLaughlin-West, T. Shank, J. Kaye, J. Hobson, J. Sarrazin, M. Sparrow, D. Hubbard, D. McGee, S. Brinson, B. Cushman. 2003. Extraordinary phase separation and segregation in vent fluids from the southern East Pacific Rise. Earth and Planetary Science Letters 206:365-378.

Wilcock, S.D., E.F. Delong, D.S. Kelley, J.A. Baross, and S.C Cary. 2004. The Subseafloor Biosphere at MidOcean Ridges. Geophysical Monograph 144. American Geophysical Union, Washington DC, 399 pp.

Yoerger, D.R., A.M. Bradley, B.B. Walden, M.-H. Cormier, and W.B.F. Ryan. 2000. Fine-scale seafloor survey in rugged deep-ocean terrain with an autonomous robot. International Conference on Robotics and Automation; San Francisco, Institute of Electrical and Electronic Engineers, 1,787-1,792. 